\section{The Standards Revisited}

by Fred Branscombe

There is no bond of union so strong as the
bond created by common dangers shared in common. $\quad$ Sir Wilfrid Laurier

We, whose primary professional con-
cern is the provision and utilization of cern is the provision and tutilization of
learning materials, are known by dozens of apparently conflicting titles and job variants of one or other of two basic terms: librarian and audio-visual for
media) specialist. We are usually found polarized in our attitudes toward technology. At one extreme, some eagerly
embrace every technological innovation Others, at the opposite extreme, are openprinted word, which because of its age is deemed to have shed the stigma which it
once had as an unwelcome new once had as an unwelcome new
technology. These differences among us ar
understandable. We are the heirs of two separate traditions. The corporate voices
for those two traditions are the Association for Media and Technology in Educa tion in Canada /formerly the Canadian
Audio-Visual Association and later the Educational Media Association of Association (a division of the Canadian Association $(a$ divinl
Library Association.

The first criteria used in Canadian
schools regarding the provision of learning materials were imported, typically, publication School Libraries for Today

Dr. Fred Branscombe is coordinator emeritus of educational media services
with the Board of Education for the City of North York. Throughout a long and distinguished career he was a pioneer in the development of AMTEC and its
precursors, CAVA and EMAC, and was active in AECT and its precursor DAVI in the co-author, with Harry Newsom, of Resource Services for Canadian
Schools. Now officially retired, Dr. tive interest in AMTEC while pursuing his writing interests. and Tomorrow, produced by the tion from the United States was still the practice in 1960 with the use of Stan-
dards for School Library Program (prepared by the American Association of
School Librarians) and again in 1966 with Audiovisual Personnel, Equipment and Materials (by the Department of Audiovisual Instruction of the National
Educational Association). Not only for reasons of national pride but also because of significant differences between educa tional goals and practices in Canada and
the United States, there was a need for distinctively Canadian standards. That need was recognized by the newly tion at its first annual meeting, held in O tawa in 1962. A standards committee was opolitan Toronto Borough of York. It produced in 1965 the Preliminary Standards for School
Libraries. That document was revised by a second standards committee, with Harry Newsom of Winnipeg as chairm
which arranged for the publication by the Ryerson Press in 1967 of the Standards
of Library Service for Canadian Schools. The publication of the C.S.L.A. Stan-
dards was a notable achievement. It was dards was a notable achievement. It was
the first Canadian standards for the prov was a pioneer, too, in recognizing that books were not the only materials tha should be available to teachers and
learners. In a bold statement that ma seem trite in 1985 but was (in 1967) a collaborators wrote, "The library collection consists of books, disc records, tapes, pictures, pamphlets, periodicals, film,
strips, film slides, microfilm, charts and museum objects - all materials which might be used to instruct, inspire as well as encourage and facilitate the learnin
programme. The librarian, as an instrucprogramme. The librarian, as an instruc-
tional materials resource person, works ministration, parents and community agencies to produce a library pro-
gramme." True, many of the non-book items in that list were old-timers, even in traditional libraries. Several had attained respectability under the rubric, Vertical my myidence in administrative decisions relative to non-print library materials in
chools. I know of a large urban secondary school where, about the time of the filmstrips were kept (along with cash
and the school records) in a walk-in vault and the school records) in a walk-in vault
in the main office and were lent from in the main office and were lent from
there by a secretary one at a time as needed which (not surprisingly) was infrequently.
The members of the Canadian AudioVisual Association welcomed the ap dards for learning materials. They ap ty of needed materials, without distinc-
tion as to format or medium. They were tion as to format or medium. They were
disappointed, however, with what they considered to be the inadequate recogni-
tion of the need for local production of non-print materials. This was particularly true in the case of production by students cess, not in the product. It was feared that this shortcoming might cause serious harm, were it come to be accepted that he responsibilities of the instructiona ther than "to acquire books and materials" and "to organize these materials for effective use."
C.A.V.A. decided that there was an urgent need for a comprehensive presen-
tation of the needs for and the difficulties in, a fully developed program for the production and distribution of non-prin materials. By the time that a book was tion had changed its name to the Educa-

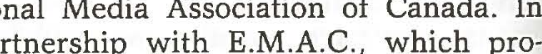
partnership with E.M.A.C., which proCanada Ltd. published in 1969 Media Canada: Guide Lines for Educators. The book, which was edited by Jame Miller of the Borough of York in and enjoyed a second printing in 1970. E.M.C.A.'s Media Canada provided much more reliable guidance than either volume did on its own. Both books had the particular professional competencies VOLUME 14, NUMBER 3, 198 tunately, each book had blind spots
reflecting the specific training experience and interests of its authors.

gressive in its advocacy of the unification -print collections and programs, whereas Media Canada a
peared to champion the already outmo ed concept of complete separation. Where
the Standards gave little or no leadershi the Standards gave little or no leadership
relative to materials production, Media covering every conceivable eventuality. Conversely, Media Canada was mute arrange non-print materials so as
arrang how to classify, atalogue an facilitate their effective use, whereas these were areas of particular strength in he C.S.L.A. Standards.

At its 1971 Annual Meeting C.S.L.A. revised edition of its 1967 Standards. To improve its credibility in advocating the unification of print and non-print collecthens and services, it included in a newly members who had outstanding credentials as audio-visual specialists. The chairLibrary Science, University of Alberta committee. Except for one problem, could have produced a set of standards for instructional materials, equally usable
relative to learning materials is all media. The problem was that, regardless of the
The ceptable to all to whom it would have been addressed. No matter whether it had been published under the auspices of
C.S.L.A. or E.M.A.C., the members of the it as a subversive plot to seize, or to keep hegemony (depending on how thing were organized locally) in the learning
materials program in the local school system. If C.S.L.A. had published its ow
revised edition, E.M.A. undoubted would have had one too, complete with
chapters in the areas where it had been weak previously.

It was obvious that the need was not separate second editions of the two books of standards, each competing with and undermining the other. The time was op-
portune for C.S.L.A. and E.M.A.C. to the Department of Audiovisual Instruction and the American Association of
School Librarians when they jointl published the Standards for Schoo Media Programs (1969).
By a happy coincidence I had an oppot- tunity in 1971 to say in print what many
members of both E.M.A.C. and C.S. were saying privately. I had been asked interface of librarians and audiovisual personnel in Canadian education. I
ook advantage of the opportunity to say
of the two Canadian books of standards, There is an urgent need for the different all the contributors to both books to be ncentrated on the production of a new of media standards for Canadian xisting publications. This is no idle theam. It can be done cooperatively by and the Educational Media Association of Canada."

D.M.A.C. and C.S.L.A. exlored the possibility of both organizarevised editions of their respective books standards, in favor of an entirely new associations. These preliminary conversations led to a formal agreement by the writing and publishing of a comservices in Candian schools to resource it was agreed that the committee that was to implement the decision, as well as its sub-committees, would have two ing associations. Gordon Jarrell, president
of the Educational Media Association of Canada, invited me in January, 1972, to Ce chairman of the existing C.S.L.A. stanco-chairma

Having witnessed some of the mighty rows over petty disputes between media levels in the United States, I found the first meeting of the Joint National Stan-
dards Committee in Winnipeg early in 1972 to be truly memorable. With four over a dozen C.S.L.A. E.M.A.C. facingers cluded that we were not about to win anything that the other side of the table remarkable thing happened that set the followed until the publication of the book in 1977 . Harry Newsom proposed that questions be settled by consensus, rather
than by voting. Furthermore, with the ap-

nounced that where it was impossible to C.S.L.A. members would vote as there were E.M.A.C. members voting. Tha

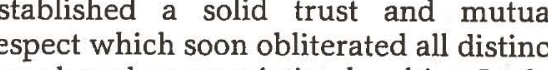
ons based on association loyalties. In the fiv votes that the national committee had infive years, the division

Contributors of ideas and authors of the Schools were organized on a two tier . Content committees were establishacters (o the remaining members of each of these sub-committees were chosen on the W.M.A.C. and C.S.L.A. members and (2) residence within a reasonable could be done without undue inconveperoup sition papers which formed them in text which was eventually developed. The co-chairmen of the sub committee (T) Brown (Winnipeg), Louise Burges Anne Davidson (Regina) Heather-Belle Dowling (Edmonton), Doris Fennell an Guilbert (Winnipeg). Kenneth David Jenkinson (Winnipeg), Neil Nelson (Toronto), Gwendaline North (Calgary),
Ray Rycroft (London), Barbara Smith Ray Rycroft (London), Barbara Smith
(Mississauga), John Stoeber (Calgary)
Marjorie Szollosy (Toronto), and John In addition to the general supervision of the project, the national standards com ing the baic philosophy of of determinnvolved reconciling minor differences in the recommendations of the sub-
committees so as to produce a unified
text. The members of the national committee were: Kenneth Bowers (Edmon, Agnes Florence (Winnipeg), Gordon (T) AcLean (Kingston) Harry Newsomce Moore monton), Margaret Scott (Toronto) Florence Willson (Prince
Robert Wylie (Belleville).

C 
debate the issue of school libraries an trivializes the major issues. While we bemoan the lack of integration of differen types of learning resources, particularly the media and their collection and organization. In an information society
more time and energy has to be devoted we have available to us in effective in structional programs to teach youngster how to process and use information. To do that, we go right back to the pro mise of Resource Services for Canathe program a role for a clear aim for sonnel which is clarified and focused good programs to prepare this staff, a
district approach to coordination of resource centres and their development programs which focus on program development and enhancement, and a
commitment to well-designed, wellintegrated resource based learning programs for young people. This is really the least we can do with any degree of profes-
sonal competence and respect.

\section{MISSION POSSIBLE}

ontinued from page 9

The standards contain both quantitative sent a compromise between 'what should be' as expressed in the literature and sent economic climate." It is intended that they be interpreted as minimum rather than desirable expectations.
The inclusion of quantitative standar or school library collections, staffing and they are seen by schools exceeding them as too low, and by those at the other end of the spectrum as impossible to attain. a urisdictions would have some difficulty phasing in the standards over a $3-5$ year period.
Following are the standards for libra

Library Staf

Professional direction is critical to the an effective program.

Professional direction may be proa) By a full-time teacher-librarian on the school staff.

time library and part-time teaching
tim assignment.
By a teacher-librarian serving more
than one school in the district. d) By supervision by a school district
(central office) teacher-librariane) By cooperative agreement with Sy cooperative agreement with
regional library system f) Where no teacher-librarian is available, by the principal and
teaching staff of the school. Note: i) The minimum qualifications of a
teacher-librarian should include teacher certification and successful teaching experience along with university credits in
at least eight half courses in
librarianship and instructional technology.
ii) Active participation on the part of the principal and teachers in
the implementation of library program must increase as teacher-librarian time is
decreased.

Qualified technical/clerical support should also be provided.
Professional and technical/clerica support should meet or exceed the $\begin{array}{lll}\text { following standards: } & \\ \text { School Teacher- Technical }\end{array}$ Librarian Clerical $\begin{array}{lcr}150 \text { Students } & & 1 / 2-1 \\ 300 \text { Students } & 1 / 2 & 1 / 2-1 \\ 500 \text { Students } & 1 & 1 \\ 750 \text { Students } & 1 & 1^{1 / 2}-2\end{array}$ 150 Students

1000 Students

$11 / 2-2$

$1 / 2-2$
2

The School Library Collection

the major collection should support tional program and represent a balanced range of student interests and needs, including the appreciation of

The size of the basic collection should enrollment served, the number of grades taught in the school, the tymber and types of instructional pro mams, and accessibility of relevant
materials through regional coopera-
tion, networking and interlibrary loan rranemerting and ing The basic library collection for a
chool of 250 students should include. print and nonprint material

magazines 4,000 titles
20 pamphlets, pictures... to meet film/video, etc. . . from Regional Fils Centre, District IMC, ACCESS
Alberta Educational Communications

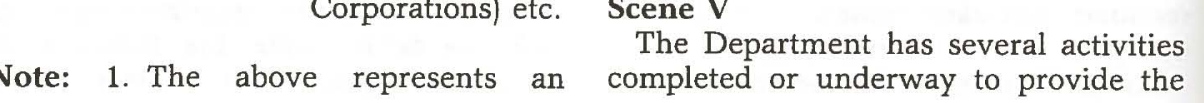

VOLUME 14, NUMBER 3, 1985

college and university libraries.
congen

The reference collection should

Schools offering programs in both English and languages
other than English, should increase the basic collection to inmaterials (print and nonprint) to support instruction in the
language|s offered. Selection criteria for the library collection should be consistent
with:
a) Guidelines for tolerance and statement. c) Canadian content priorities.
d) Identified library program f) Information from recognized chase of new materials, supplies and equipment lif equip-
ment is not provided for in the budget categoryl The budget realize library program goals
and objectives. It should be recognized that smaller schools and schools offering programs a higher than average evaluations. Added to these priorities
for $1985 / 86$ is school libraries. The grants provide for $\$ 9.00$ per pupil in
grades one through twelve, and $\$ 5.40$ per early childhood services student.
The guidelines for this funding focus proved classroom instruction. areas have been identified by Alberta Education for additional funding. These may vary from year to year. For $1985 / 86$, additional support will be
given for the enhancement of school given for the enhancement of school
library learning resource collections. These funds will be allocated to school boards on the basis of $\$ 10.00$ per stu-
dent or $\$ 1000.00$ per school which ever is greater. The funds are to be aption for, the funds normally allocated for the development of library collec-
tions. In June 1986, boards will be extions. In June 1986, boards will be ex-
pected to make an interim report of pected to make an interim report of ding, with a final report in June, 1987.
School boards will be required to have on activities which will result in im-

documents on file that are consisten
with the new library policy; a plan for priority needs for collection develop. policy aproved by the and selection The 4500 responses to the questionnaire are a testimony to the commitment rvices - from the leading man, David King, Minister of Education, to the 'cas vincial library association, strongly sup-

ported by parents.
Educators have given a standing ova Education. Curtain calls are inevitable. ption of this model will be available to all Alberta schools, spring Throughout discussions related to the made to the need for inservice educational programmes for teacherministrators. In 1984, Alberta Eduction etsablished a new fund for teach priority areas of computer literacy

include at least one
general encyclopedi a) Guidelines for tolerance and
understanding.
b) Controversial issues policy e) Needs identified by students should be allool library budget should be determined on the in English as well as languages

Harry Newsom (from his base in Ed-
nonton and later in Kamloops) worked monton and later in Kamloops) worked situated in Winnipeg, Regina, Calgary, and London. Meetings of the nationa
committee were held in Edmonton, Win
STANDARDS REVISITED

continued from page 5. Edmonton and
located in Toronto, I related with the
groups in St. Catharines, Toronto, Guelph groups in St. Catharines, Toronto, Guelph
and London. Meetings of the national nipeg and Toronto. These had to be kept to a minimum because of the costs involved. The principal coordination of the
work of the various groups in western work of the various groups in western
and central Canada was achieved by frequent meetings between Harry Newsom
and me. Most of these work sessions were held in Winnipeg, although some were in Oronto and Kamloops.

Neither the Canadian School Library
Association nor the Educational Medi Association of Canada (or its successor,
the Association for Media and the Association for Media and
Technology in Education in Canadal had he financial resources to support ac-
tivities on such a large scale. The prepara tion of the manuscript might well have
been impossible had it not been for the been impossible had it not been for the
generous grant of $\$ 12,000.00$ by the World Book Encyclopedia of Chicago and Toronto. With that assistance it was possi-
ble to pay for the postage, telephon charges and travelling expenses that were We have now come full cycle in 1985 and it is again time to consider revision of vices for Canadian Schools. We have today the same two options which we had in 1971: two separate books (one each
published by C.S.L.A. and A.M.T.E.C.) or a single set of standards published by the two associations jointly.
The convenience is tempting for each ment of the true faith from its point of view, without the bother of developing a
consensus with others in the field. It would be the easier way to go and more conducive to ego trips, both corporate and personal. It would, however, be a derelic tion of duty.

The dangers which we face as librarians and media specialists, we face in com-
mon. When reduced funding undermines the provision of learning mateirals, all are affected. The negativism of the "back to
basics" revisionists makes no distinction between us. Neither books nor films are safe from witch hunts. We are attacked in common and we must defend ourselves together. Any revision or the replacement
of the present standards must be a joint of the present standards must be a joint
A.M.T.E.C. - C.S.L.A. project. The central issue is whether we want to
tocommed unified standards or to

CANADIAN JOURNAL OF EDUCATIONAL COMMUNICATION
REFERENCES

school libration. (1984). Alberta school libraries

(1984). Policy, guidelines, procedures and stan-
dards for school libraries in
Alberta. Edmonton, AB: Author. retrogress to separate sets of recommen-
dations. It is not whether it should be ingle larger book or a series of smaller oces dealing with various particularities d herring. Either comprehensive or odular publications can be produced options is to publish two separate books or, if we go the modular route, ten or ach other for sales, subtly contradicting nd lessening one another's credibility. Our other option is to develop a consensus and to speak with united conviction and doubled authority to those who need ing materials in all media and to be The members of the Association for Cedia and Technology in Education in Library Association have an obligation to present the case for the acquisition, prouction and utilization of learning materials in every medium, not com ne association at the expense of the other, but cooperatively in a bond of and librarians alike, the means of obtaindangers and of achieving greater success in common endeavors. hown how to use them effectively. 